\title{
乳酸桿菌の生物学的特性について
}

\section{I. 乳酸桿菌の抗生物質感受性試験法}

\author{
遠山 清 寺島 経 男 \\ ヤクルト研究所 \\ 国立市谷保1796 宁186 \\ 〔受付：1月 7 日, 1974年〕
}

\begin{abstract}
通性㨀気性菌である乳酸桿菌の抗生物質感受性試験法について, ディスク法の改良を試 みるとともに，この方法を応用して乳酸桿菌の抗生物質に対する自然耐性を調べた。

供試菌の接種方法を軟寒天重層法に改良することによつて,ディスク法による感受性試 験法を確立した。接種菌量は濁度を130-160クレット単位に調整した20時間培養の $0.1 \mathrm{~m} l$ を用いた場合に良好な成績が得られた。テトラサイクリン, リンコマイシン，オレアンド マイシン, ペニシリンG, エリスロマイシン, クロラムフェニコールで検討した結果, デ イスク法で得られた最小阻止湦度 (MIC) は, 平板希釈法, 此濁法で得られた発育許容最 高濃度（仮称；菌の発育が認められた最高の薬剤濃度）ときわめて良く一致した。

7 菌種（species），34菌株（strains）について，17 種類の抗生物質に対する感受性分布 を調べた。Lactobacillus acidophilus, L. jugurti を例外として，供武株はストレプトマ イシン系薬剤にはきわめて抵抗性が強く, 逆にマクロライド系薬珮, ミカマイシン, ペニ シリン G，テトラサイクリンには感受性が高かつた。セファロシン感受性は菌種により差 があり, L. casei が特異的に相当強い抵抗性を示した。
\end{abstract}

近年化学療法鼡の使用頻度が高まるとともに薬剤耐性 菌の出現 ${ }^{13)}$, 菌交代症 ${ }^{2,8)}$, 薬羭自体の薬害 ${ }^{2}$ が医学上問 題となつている。一部の腸疾患や抗生物質投与後の消化 管障害の改善の一方法として, 乳酸菌, ビフィズス菌な どの投与が考えられている2,99。

抗生物質に対する乳酸桿菌および他の非病原細菌の薬 鼡感受性試験に関する詳細な報告はほとんどみられな い。乳酸桿菌のような通性娧気性菌は, 従来好気性菌で 行われてきた in vitro 感受性試験法を適用できない場 合が多い。平板希䣋法は, 乳酸桿菌では平板表面に増殖 しにくい菌種があり, かつ菌の増殖限界值付近の抗生物 質濃度では菌の增殖の有無を判定しにくく間違いやす い。比濁法は多数の菌株を扱うには繁雑すぎ，ディスク 法は簡単ではあるが平板表面での増殖性の問題から阻止 円境界が不明瞭となる欠点があつた。

著者らは, 一連の腸内細菌科のいわゆる非病原菌種の 抗生物質感受性について検討を加えつつあるが，今回乳 酸桿菌についてその試験法を確立するとともに．その感
受性度について検討したので報告する。

\section{材料と方法}

供試菌株：感受性試験の検討には, Lactobacillus casei YIT0091 (ヒト大便由来), L. acidophilus A-28, L. fermenti F-1 (英国国立酪農研究所 M. E. Sharpe 博士より分与), L. fermenti ATCC14931, L. salivarius S-161, S-223, S-436 (ヒト大便由来) および $L$. salivarius ATCC11741 の 8 株を用いた。感受性分布の 供試株は， L. casei 15 株， L. acidophilus 5 株， L. salivarius 8 株, L. fermenti 3 株, L. plantarum, L. jugurti, L. bulgaricus 各 1 株の計34株を用いた。

試藤：感受性ディスクは，市販の昭和ディスク（日水 製薬製 1 濃度ディスク)を用いた。使用ディスク名は， エリスロマイシン (EM)，オレアンドマイシン (OL), ロイコマイシン $(\mathrm{LM})$, スピラマイシン $(\mathrm{SPM})$, テト ラサイクリン ( $\mathrm{TC})$, ストレプトマイシン (SM), カナ マイシン $(\mathrm{KM})$, フラジオマイシン (FRM), パロモマ 
イシン (PRM), クロラムフェニコール (CP)， ミカマ イシン (MK), リンコマイシン (LCM), ペニシリン (PC-G), セファロリジン (CER), セファロシン(CET), ノボビオシン $(\mathrm{NB})$, デヒドロオキシメチルフラクトリ シンン（FT）の17種類である。

抗生物受感受性測定法: 菌株は平板表面で良く增殖す る菌と增殖しにくい菌とを用いて次の 3 種の方法を比較 した。

平板希釈法8); Rogosa の培地 ${ }^{5}$ )を用いて調製した 2 倍 段階濃度に抗生物質を含む平板に, 供試菌培養液を 0.005 $\mathrm{m} l$ ずつスポット後 $37 \mathrm{C} て ゙$ 培養した。18～20 時間後, 菌 の増殖が認められない最低濃度をむつて最小発育阻止濃 度 (MIC, $\mu \mathrm{g}$ または unit $/ \mathrm{m} l)$ とし, 菌の発育が認め られた最高濃度を発育許容最高濃度 (MTC, $\mu \mathrm{g}$ または unit $/ \mathrm{m} l$ ) と仮称した。MTC 值は MIC 值より 1 段階 （1/2）低い濃度である。

比濁法 ${ }^{3)}$; Rogosa の培地を用い,抗生物質を 2 倍段階 希釈して系列希釉液を調製した。供試菌の20時間培養を クレット光電比色計で濁度 $130 \sim 150$ 亿調製した。この $0.03 \mathrm{~m} l$ を上記の培地 $3 \mathrm{~m} l$ に接種 $\left(0.8 \sim 1.3 \times 10^{7} / \mathrm{m} l\right)$ 後18〜20時間培養した。判定はクレット光電比色計で濁 度を測定し, クレット単位 $25\left(5 \times 10^{7} / \mathrm{m} l\right)$ 以下を增殖 なしとした。なお MIC 值, MTC 值は平板希釈法の項
に準じた。

ディスク法；供試菌の接種はファージの plaque assay に使用される軟寒天重渞法1)を用いた。Rogosa の培地 の平板に供試菌（クレット単位130-160）の $0.1 \mathrm{ml}$ を 溶解した軟寒天培地（寒天 $0.6 \%$ ） $2.5 \mathrm{ml}$ とともに重層 した。ただちにディスクを置き，室温で30分放置後 $37 \mathrm{C}$ で18〜20時間培養した。生じた阻止円直径をノギスで計 測し,ディスク専用の判定表（日水製薬）から MIC 值 を算出した。

乗郕耐性変異株の分離 : L. casei YIT0091，L，acidophilus A-28 の 2 株の EM, OL, LM, TC, SM, CP の単鼡あるいは多鼡耐性菌を分離した。マクロライド (Mac) 系薬荗, TC, CP の耐性化は，それぞれ $\mathrm{EM}$, TC, CP 含有 Rogosa 液体培地で増量的継代 ${ }^{8)}$ をて分 離した。SM 耐性菌は紫外線照射による1段誘起法によ り分離した。

\section{成}

ディスク法による取小発充阻止浱度測定におよほす接 程菌量の影㬖：供試菌は軟寒天で重層して接種した場合 には, 平板表面でほとんど增殖しないL. bulgaricus や L. acidophilus でも均一に增殖し, 明瞭な阻止円境界が 得られた。そこで軟寒天重風ディスク法（ディスク法と

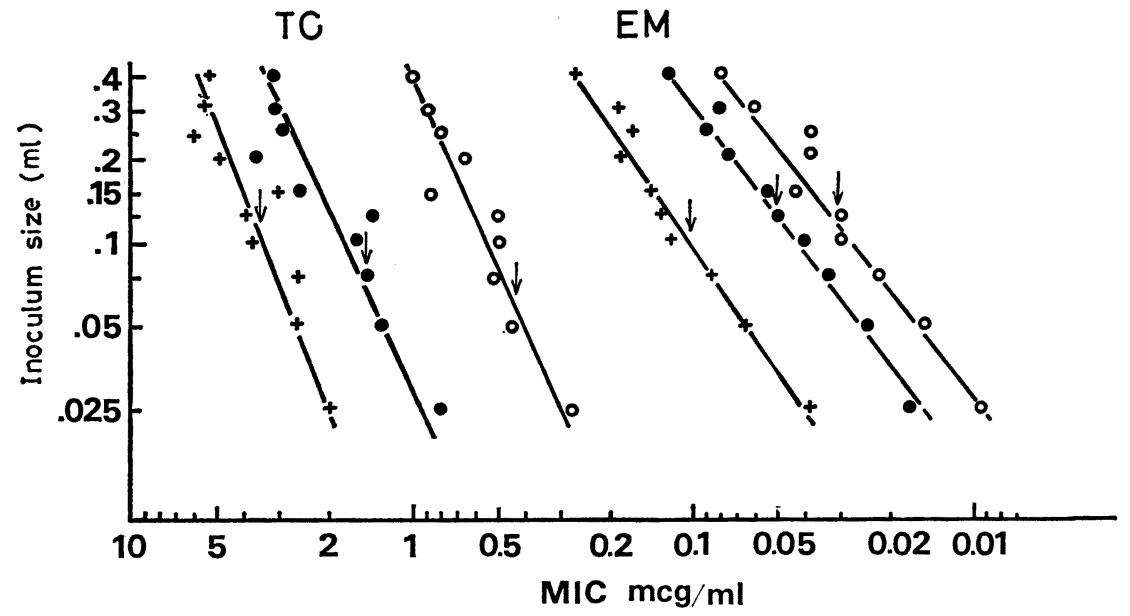

Fig. 1. Effect of inoculum size on minimum inhibitory concentration of antibiotics. Bacterial suspensions were prepared from overnight cultures by adjusting their O. D. to 130-160 Klett units. Varying amounts of the suspensions were mixed with $2.5 \mathrm{~m} l$ of melted Rogosa's soft-agar medium and overlayed on the same agar medium. Then MIC were determined by disc method. Arrows indicate maximum tolerant concentration of visible growth (MTC), which was obtained by agar dilution method. $\bigcirc:$ L. casei YIT0091, - : L. fermenti ATCC14931, +: L. fermenti F-1. 


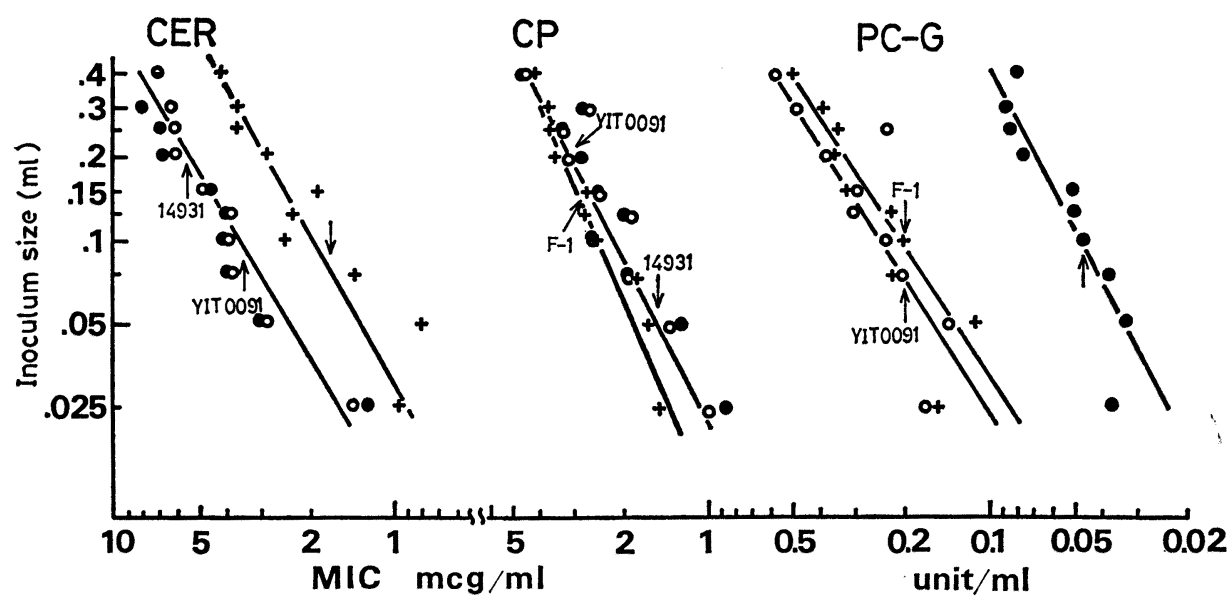

Fig. 2. Effect of inoculum size on minimum inhibitory concentration. Conditions and symbols are same as indicated in Fig. 1.

略す）を用いて検討を加えた。

困 1 〜 に MIC 值に与える按種菌量の影響を示す。 供試菌は L. casei 1 株と L. fermenti 2 株を用いた。 接種菌量を $0.025 \mathrm{~m} l \sim 0.4 \mathrm{~m} l$ に変えたときの $\mathrm{MIC}$ 值は，接種量が多くなると直線的に増加した。しかも同 一抗生物質においては, 各供試菌に対応するこの直線は 平行線となつた。したがつて菌株間における MIC 值の 変動幅は, $\mathrm{TC} 2.5 \sim 3$ 倍, $\mathrm{EM} 6 \sim 8$ 倍, $\mathrm{CP} 4 \sim 5$ 倍, CER 4〜5倍, PC $3 \sim 5$ 倍とほぼ等しくなつた。 一定の接種菌量を公める一方法として, これらの抗生 物質について平板希釈法で求めた MIC 值と発育許容最 高濃度 (MTC 值) とを図 $1 \sim 2$ と比較した。 MIC 值 より 1 段階低い濃度である MTC 值をプロットすると (図中矢印) 接種菌量 $0.075 \sim 0.15 \mathrm{ml}$, 特に $0.1 \mathrm{ml}$ 付 近の接種菌量で得られる MIC 值に良く一致した。接種 菌量が $0.075 \mathrm{~m} l$ より少ないと, 菌の增殖が薄いために 阻止円全体が見にくくなり，また $0.2 \mathrm{ml}$ より多くなる と菌の増殖が濃すぎるために址此境界の内側に $1 \sim 5$ $\mathrm{mm}$ の薄い菌の增殖带が生じ，阻止円境界が不明瞭とな る傾向があつた。したがつて以後接種量は $0.1 \mathrm{ml}$ に固 莣した。

ディスク法, 平板希釈法, 比濁法による感受性値の比 較：平板表面で良く增殖する L. casei YIT 0091， L. salivarius S-161 と增殖しにくい L. acidophilus A-28 を用いてディスク法, 平板希釈法, 比濁法で得られた成 績を比較した(表 1 )。抗生物質は OL, LCM, EM, CP, TC, PC-G の 6 種類を用いた。平板法, 比濁法で求め た MTC 值は, 図 $1 \sim 2$ の成績を再現して, ディスク
法により求めた MIC 值と良く一致した。ディスク法と 他の 2 方法の值の変動幅は, どの供試菌の場合でもすべ ての抗生物質にわたつて約 2 倍の範囲内であつた。この 事実はさらに L. salivarius 4 株, L. fermenti 1 株を 用いてディスク法と比濁法とによつて確認された（表 2)。すなわち EM, OL, TC, CP とも変動幅 $2 \sim 4$ 倍 の範囲内で良く一致した。また L. casei YIT0091 株の TC, CM 低濃度耐性菌や, L. acidophilus A-28 の OL 低濃度耐性菌を用いて比較した（表 2 ）。耐性菌のよう に比較的 MIC 值が高い場合でも比濁法の MTC 值と ディスク法の MIC 值は良く一致した。したがつて接種 菌量を一定にすれば，一定の MIC 值が值られ，しかも $0.1 \mathrm{ml}$ の接種菌量では, 平板希秎法や比濁法で得られ る MTC 值に良く一致する成績が得られることが明らか となつた。

乳酸秙菌の抗生物翼感受性分布 : ディスク法によつて 17 種類の抗生物質に対する乳酸桿菌の感受性分布を調べ た。表 $3 \sim 5$ の MIC 值はディスク法で求めた MIC を 整理区分し, $0.0125 \mu \mathrm{g} / \mathrm{m} l$ 末満を $\angle 0.0125,0.0125 \leqslant$ $\angle 0.025 \mu \mathrm{g} / \mathrm{m} l$ の範囲に含まれるものを $0.0125 \mu \mathrm{g} / \mathrm{m} l$ というょうに定め, 以下同様の区分で示した。なお成績 は各 MIC 区分に含まれる菌株数で示した。

表 3 は Mac 系抗生物質, CP, MK, TC, LCM に対 する感受性分布である。ここに示した抗生剤は，乳酸桿 菌に対する阻止作用の強いものが多かつた。とりわけ $\mathrm{EM}, \mathrm{LM}, \mathrm{MK}$ では, MK の1株を例外として供試株 すべてが $0.4 \sim 0.8 \mu \mathrm{g} / \mathrm{m} l$ 以下の感受性域に分布した。 他の薬㰾についても $3.2 \mu \mathrm{g} / \mathrm{m} l$ の濃度域を限界として, 
Table 1. Comparison of sensitivity values to antibiotics determined by modified disc, tube dilution and agar dilution methods

\begin{tabular}{lllll}
\hline & & \multicolumn{3}{c}{ Sensitivity values determined by } \\
\cline { 3 - 5 } & & $\begin{array}{c}\text { Agar } \\
\text { dilution }^{a}\end{array}$ & $\begin{array}{c}\text { Tube } \\
\text { dilution }^{a}\end{array}$ & $\begin{array}{c}\text { Paper } \\
\text { disc }^{b}\end{array}$ \\
\hline EM & YIT0091 & 0.05 & 0.025 & 0.022 \\
& A-28 & 0.025 & 0.05 & 0.013 \\
& S-161 & 0.1 & 0.1 & 0.076 \\
OL & YIT0091 & 0.8 & 0.4 & 0.35 \\
& A-28 & 0.1 & 0.1 & 0.08 \\
& S-161 & 1.6 & 0.8 & 1.4 \\
LCM & YIT0091 & 0.2 & 0.4 & 0.32 \\
& A-28 & 0.2 & 0.2 & 0.1 \\
& S-161 & 1.6 & 0.8 & 1.15 \\
TC & YIT0091 & 0.4 & 0.2 & 0.29 \\
& A-28 & 0.4 & 0.2 & 0.19 \\
& S-161 & 0.4 & 0.2 & 0.21 \\
CP & YIT0091 & 3.2 & 3.2 & 3.9 \\
& A-28 & 1.6 & 1.6 & 0.8 \\
& S-161 & 1.6 & 0.8 & 0.97 \\
PC-G & YIT0091 & 0.4 & 0.8 & 0.31 \\
& A-28 & 0.05 & 0.05 & 0.02 \\
& S-161 & 0.2 & 0.2 & 0.15 \\
\hline \multirow{4}{*}{. } & & &
\end{tabular}

a Sensitivity values were represented by maximum tolerant concentration for visible growth (MTC mcg or unit $/ \mathrm{m} l$ ).

${ }^{b}$ Minimum inhibitory concentration (MIC mcg or unit $/ \mathrm{m} l)$.

YIT0091: L. casei, A-28: L. acidophilus, S-161:

L. salivarius.

それ以上の MIC をもつ株は検出されなかつた。ただ $\mathrm{CP}$ では $1.6 \sim 3.2 \mu \mathrm{g} / \mathrm{m} l$ の濃度域に供試株の約 $50 \%$ 分布し, やや抵抗性の強い傾向があり, 同様のことが SPM でもみられた。

PC-G，CER，CET，NB，FT の感受性分布は表 4 に 示した。PC-G の阻止作用はきわめて強く, 供試株は $0.4 \mathrm{unit} / \mathrm{m} l$ 以下の感受性の濃度域に分布した。例外々 して $1.6 \mathrm{unit} / \mathrm{m} l$ に L c casei 1 株が分布した。この株 は CET に対する MIC 值が $30.5 \mu \mathrm{g} / \mathrm{m} l$ と高いこと から耐性菌と思われる。一方 CER, CET, NB, FT の 分布は散在型で広範囲に分布した。CET の $3.2 \sim 25$ $\mu \mathrm{g} / \mathrm{m} l$ に分布する $13 / 34$ 株の菌は, L. fermenti の 1 株
Table 2. Comparison of sensitivity values to antibiotics obtained by modified disc and tube dilution-methods

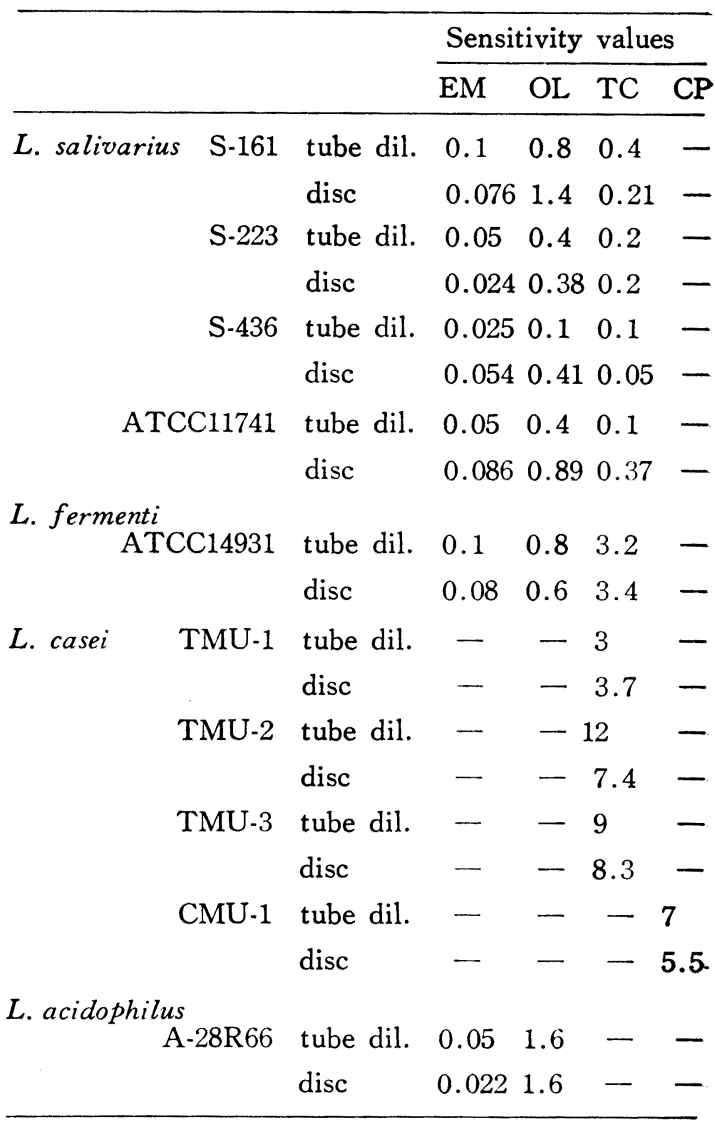

Sensitivity values were presented same as those in Table 1.

を例外としてすべて L. casei で占められていた。この 事実は，L. casei が CET に対して抵抗性の強い菌種 であることを示唆する。しかしながら CER, NB, FT では,このような一定の型はみられず, 菌株(strain)に よる差の大きいことが明らかとなつた。

以上の抗生物質と比較すると, 乳酸桿菌は SM 系楽 凨に対して非常に強い抵抗性を示し心（表 5 )。特に $\mathrm{KM}, \mathrm{PRM}, \mathrm{FRM}$ では, ディスク法の測定限界外に MIC 值をもつ菌が KM で20/34, PRM 26/34, FRM 19/34 株と供試菌の大部分を占めていた。一方 SM の分 布は多少異なり， $25 \sim 50 \mu \mathrm{g} / \mathrm{m} l$ にピークをもつ分布が 得られた。なかでも L. acidophilus は SM に対し感受 性が強く, 供試 5 株すべてが $1.6 \sim 6.3 \mu \mathrm{g} / \mathrm{m} l$ の低浱度 域に分布した。 
Table 3. In vitro sensitivities to antibiotics of Lactobacillus

\begin{tabular}{|c|c|c|c|c|c|c|c|c|c|c|c|c|}
\hline \multirow{2}{*}{\multicolumn{2}{|c|}{ No. of strains tested }} & & \multicolumn{10}{|c|}{ MIC mcg per $\mathrm{m} l$} \\
\hline & & & \multirow{6}{*}{$\frac{3.2}{0}$} & \multirow{6}{*}{$\frac{1.6}{0}$} & \multirow{3}{*}{$\frac{0.8}{0}$} & \multirow{2}{*}{$\frac{0.4}{1}$} & \multirow{2}{*}{$\frac{0.2}{0}$} & \multirow{2}{*}{$\frac{0.1}{3}$} & \multirow{2}{*}{$\frac{.05}{8}$} & \multirow{2}{*}{$\frac{.025}{3}$} & \multirow{2}{*}{$\frac{.0125}{9}$} & \multirow{2}{*}{$\frac{<.0125}{10}$} \\
\hline & Total & 34 & & & & & & & & & & \\
\hline \multirow{6}{*}{$\mathrm{EM}$} & L. casei & 15 & & & & & & 1 & 4 & 1 & 4 & 4 \\
\hline & L. acidophilus & 5 & & & & & & & & 1 & 3 & 1 \\
\hline & L. salivarius & 8 & & & & & & 1 & 3 & & 1 & 3 \\
\hline & Other species ${ }^{a}$ & 6 & & & & & & 1 & 1 & 1 & 1 & 2 \\
\hline & Total & 34 & 0 & 0 & 1 & 3 & 3 & 8 & 4 & 8 & 4 & 3 \\
\hline & L. casei & 15 & & & & 2 & 1 & 4 & 3 & 3 & 1 & 1 \\
\hline \multirow[t]{5}{*}{ LM } & L. acidophilus & 5 & & & & & & & & 3 & 2 & \\
\hline & L. salivarius & 8 & & & 1 & 1 & 1 & 2 & & 1 & 1 & 1 \\
\hline & Other species & 6 & & & & & 1 & 2 & 1 & 1 & & 1 \\
\hline & Total & 34 & 0 & 2 & 1 & 11 & 7 & 5 & 4 & 2 & 1 & 1 \\
\hline & L. casei & 15 & & & & 4 & 5 & 2 & 3 & & 1 & \\
\hline \multirow[t]{5}{*}{$\mathrm{OL}$} & L. acidophilus & 5 & & & & 2 & & 2 & & 1 & & \\
\hline & L. salivarius & 8 & & 2 & 1 & 2 & 1 & 1 & 1 & & & \\
\hline & Other species & 6 & & & & 3 & 1 & & & 1 & & 1 \\
\hline & Total & 34 & 1 & 8 & 6 & 12 & 4 & 2 & 1 & 0 & 0 & 0 \\
\hline & L. casei & 15 & & 4 & 3 & 6 & 1 & 1 & & & & ; \\
\hline \multirow[t]{5}{*}{ SPM } & L. acidophilus & 5 & & & & 1 & 3 & 1 & & & & \\
\hline & L. salivarius & 8 & 1 & 3 & & 4 & & & & & & \\
\hline & Other species & 6 & & 1 & 3 & 1 & & & 1 & & & \\
\hline & Total & 34 & 3 & 1 & 0 & 6 & 6 & 9 & 6 & 3 & 0 & 0 \\
\hline & L. casei & 15 & & & & 3 & 3 & 4 & 5 & & & \\
\hline \multirow[t]{5}{*}{$\mathrm{TC}$} & L. acidophilus & 5 & & 1 & & & & 3 & & 1 & & \\
\hline & L. salivarius & 8 & & & & 1 & 3 & 2 & 1 & 1 & & \\
\hline & Other species & 6 & 3 & & & 2 & & & & 1 & & \\
\hline & Total & 34 & 4 & 11 & 6 & 8 & 3 & 1 & 1 & & & \\
\hline & L. casei & 15 & 3 & 7 & 4 & 1 & & & & & & \\
\hline \multirow[t]{5}{*}{$\mathrm{CP}$} & L. acidophilus & 5 & & & & 4 & 1 & & & & & \\
\hline & L. salivarius & 8 & & 2 & 2 & 3 & & 1 & & & & \\
\hline & Other species & 6 & 1 & 2 & & & 2 & & 1 & & & \\
\hline & Total & 34 & 1 & 0 & 0 & 5 & 6 & 12 & 9 & 0 & 0 & 1 \\
\hline & L. casei & 15 & & & & 2 & 4 & 7 & 2 & & & \\
\hline \multirow[t]{5}{*}{ MK } & L. acidophilus & 5 & & & & & & 1 & 4 & & & \\
\hline & L. salivarius & 8 & & & & 2 & 2 & 2 & 2 & & & \\
\hline & Other species & 6 & 1 & & & 1 & & 2 & 1 & & & 1 \\
\hline & Total & 34 & 3 & 3 & 5 & 6 & 7 & 5 & 2 & 3 & 0 & 0 \\
\hline & L. casei & 15 & & 1 & 1 & 3 & 4 & 4 & 2 & & & \\
\hline \multirow[t]{3}{*}{ LCM } & L. acidophilus & 5 & 1 & & 2 & & 2 & & & & & \\
\hline & L. salivarius & 8 & 1 & 2 & 2 & 3 & & & & & & \\
\hline & Other species & 6 & 1 & & & & 1 & 1 & & 3 & & \\
\hline
\end{tabular}

MIC values obtaines by modified disc method were grouped as follows; $\angle 0.0125,0.0125 \leq \angle 0.025$, $0.025 \leq \angle 0.05 \mathrm{mcg} / \mathrm{m} l$ and so on. Then, they were expressed as $\angle 0.0125,0.0125,0.025 \mathrm{mcg} / \mathrm{m} l$ etc., respectively.

- They include three strains of $L$. fermenti, one of L. plantarum, one of L. bulgaricus and one of $L$. jugurti. 
Table 4. In vitro sensitivities to antibiotics of Lactobacillus

\begin{tabular}{|c|c|c|c|c|c|c|c|c|c|c|c|c|c|c|c|}
\hline \multirow{2}{*}{\multicolumn{3}{|c|}{ No. of strains tested }} & \multicolumn{13}{|c|}{ MIC mcg per $\mathrm{m} l$} \\
\hline & & & \multirow{2}{*}{$\frac{25}{0}$} & \multirow{2}{*}{$\frac{12.5}{0}$} & \multirow{2}{*}{$\frac{6.3}{0}$} & \multirow{2}{*}{$\frac{3.2}{0}$} & \multirow{2}{*}{$\frac{1.6}{1}$} & \multirow{2}{*}{$\frac{0.8}{0}$} & \multirow{2}{*}{$\frac{0.4}{4}$} & \multirow{2}{*}{$\frac{0.2}{8}$} & \multirow{2}{*}{$\frac{0.1}{10}$} & \multirow{2}{*}{$\frac{.05}{1}$} & \multirow{2}{*}{$\frac{.025}{3}$} & \multirow{2}{*}{$\frac{.0125}{5}$} & \multirow{2}{*}{$\frac{<.0125}{2}$} \\
\hline & Total & 34 & & & & & & & & & & & & & \\
\hline & L. casei & 15 & & & & & 1 & & 4 & 5 & 5 & & & & \\
\hline \multirow{5}{*}{ PC-G } & L. acidophilus & 5 & & & & & & & & & 1 & & 2 & 2 & \\
\hline & L. salivarius & 8 & & & & & & & & 2 & 2 & & 1 & 3 & \\
\hline & Other sp. & 6 & & & & & & & & 1 & 2 & 1 & & & 2 \\
\hline & Total & 34 & 0 & 0 & 2 & 2 & 7 & 6 & 6 & 4 & 3 & 1 & 3 & & \\
\hline & L. casei & 15 & & & 2 & 1 & 5 & 2 & 4 & 1 & & & & & \\
\hline \multirow{5}{*}{ CER } & L. acidophilus & 5 & & & & & & & 2 & 1 & 2 & & & & \\
\hline & L. salivarius & 8 & & & & & 1 & 4 & & 1 & & 1 & 1 & & \\
\hline & Other sp. & 6 & & & & 1 & 1 & & & 1 & 1 & & 2 & & \\
\hline & Total & 34 & 1 & 4 & 6 & 2 & 5 & 2 & 4 & 3 & 3 & 1 & 1 & 2 & \\
\hline & L. casei & 15 & 1 & 4 & 6 & 1 & 3 & & & & & & & & \\
\hline \multirow[t]{5}{*}{ CET } & L. acidophilus & 5 & & & & & & 2 & 1 & 1 & 1 & & & & \\
\hline & L. salivarius & 8 & & & & & & & 3 & 1 & 1 & 1 & & 2 & \\
\hline & Other sp. & 6 & & & & 1 & 2 & & & 1 & 1 & & 1 & & \\
\hline & Total & 34 & 0 & 0 & 1 & 1 & 2 & 9 & 8 & 7 & 2 & 3 & 0 & 0 & 1 \\
\hline & L. casei & 15 & & & 1 & & 1 & 5 & 2 & 4 & 1 & & & & \\
\hline \multirow[t]{5}{*}{ NB } & L. acidophilus & 5 & & & & & & 1 & 2 & 2 & & & & & \\
\hline & L. salivarius & 8 & & & & & & 2 & 1 & 1 & 1 & 3 & & & \\
\hline & Other sp. & 6 & & & & 1 & 1 & 1 & 3 & & & & & & \\
\hline & Total & 34 & 0 & 3 & 2 & 1 & 6 & 5 & 5 & 8 & 3 & 1 & 0 & 0 & 0 \\
\hline & L. casei & 15 & & & 2 & & 2 & 2 & 3 & 3 & 3 & & & & \\
\hline \multirow[t]{3}{*}{ FT } & L. acidophilus & 5 & & 2 & & 1 & 1 & & & 1 & & & & & \\
\hline & L. salivarius & 8 & & & & & 2 & 1 & 1 & 4 & & & & & \\
\hline & Other sp. & 6 & & 1 & & & 1 & 2 & 1 & & & 1 & & & \\
\hline
\end{tabular}

MIC values were expressed as those in Table 3. PC-G; unit per $\mathrm{m} l$.

\section{考察}

ディスク法の変法による乳酸桿菌の抗生物質感受性試 験法について検討した。ディスク法の場合, 使用する培 地, 供試株の接種方法および接種量が異なると, 抗生物 質の拡散速度, 供試菌の増殖速度が変る結果として, 成 績にも大きく影響することが経験的に知られている ${ }^{16)}$ 。 著者らは,この点を考慮して検討した。その結果ディス ク法の接種菌量と MIC 值は直線関係にあり, また各供 試株に対応する直線は同一抗生物質では平行関係にある ことが示された。この事実は一定の接種菌量を用いれば どの供試株でも一定の成績が得られることを意味する。 したがつて著者らは, 平板希釈法あるいは比濁法で得ら れた MIC 值, MTC 值をマーカーとして接種菌量を検 討し定めたものである。
一濃度ディスクを用いた抗生物質感受性試験法は, 乳 酸桿菌以外では比較的良く検討されている $6,11,12,15,16) 。$ 著者らの成績で, $0.1 \mathrm{~m} l$ の接種菌量で得られた阻止円 直径と MIC 值との関係を䠖気性菌を用いた Wilkinsら 16)や, 大腸菌, 腸球菌, Pseudomonas などを用いた Matsen ら ${ }^{11)}$ regression curveにプロットすると, 非 常に良く一致して載ることが明らかとなつた。Wilkins らの方法は，供試菌を寒天培地中に混釈する方法を用い ており，しかも $\mathrm{CO}_{2}$ 置換による嫝気培養を採用してい る。このような変法で求めた Wilkins らの成績が Matsen らの成績と良く一致し，さらに著者らの成績が前 2 者の regression curve 上に良く一致してプロットで きる事実は, 平板希釈法, 比濁法の成績をマーカーとし て一定の接種菌量を求めた著者らの方法の信頼性を裏つ けるものといえる。SM について1菌株を用いて, 測定 
Table 5. In vitro sensitivities to antibiotics of Lactobacillius

\begin{tabular}{|c|c|c|c|c|c|c|c|c|c|c|}
\hline & \multirow{2}{*}{\multicolumn{2}{|c|}{ No. of strains tested }} & \multicolumn{8}{|c|}{ MIC mcg per $\mathrm{m} l$} \\
\hline & & & $\supseteq 84$ & 50 & 25 & 12.5 & 6.3 & 3.2 & 1.6 & 0.8 \\
\hline \multirow{5}{*}{$\mathrm{SM}$} & Total & 34 & 6 & 7 & 10 & 5 & 2 & 0 & 4 & 0 \\
\hline & L. casei & 15 & 1 & 2 & 8 & 4 & & & & \\
\hline & L. acidophilus & 5 & & & & & 2 & & 3 & \\
\hline & L. salivarius & 8 & 5 & 2 & & 1 & & & & \\
\hline & Other sp. & 6 & & 3 & 2 & & & & 1 & \\
\hline \multirow{6}{*}{ KM } & Total & 34 & 20 & 11 & 2 & 1 & 0 & 0 & 0 & 0 \\
\hline & L. casei & 15 & 8 & 6 & 1 & & & & & \\
\hline & L. acidophilus & 5 & 4 & 1 & & & & & & \\
\hline & L. salivarius & 8 & 8 & & & & & & & \\
\hline & Other sp. & 6 & & 4 & 1 & 1 & & & & \\
\hline & & & - & - & - & $\supseteq 12.5$ & 6.3 & 3.2 & 1.6 & 0.8 \\
\hline \multirow{5}{*}{ PRM } & Total & 34 & & & & 26 & 6 & 2 & 0 & 0 \\
\hline & L. casei & 15 & & & & 10 & 4 & 1 & & \\
\hline & L. acidophilus & 5 & & & & 4 & 1 & & & \\
\hline & L. salivarius & 8 & & & & 8 & & & & \\
\hline & Other sp. & 6 & & & & 4 & 1 & 1 & & \\
\hline \multirow{5}{*}{ FRM } & Total & 34 & & & & 19 & 11 & 4 & 0 & 0 \\
\hline & L. casei & 15 & & & & 6 & 7 & 2 & & \\
\hline & L. acidophilus & 5 & & & & 5 & & & & \\
\hline & L. salivarius & 8 & & & & 7 & 1 & & & \\
\hline & Other sp. & 6 & & & & 1 & 3 & 2 & & \\
\hline
\end{tabular}

MIC values were expressed as those in Table 3.

回数50回の MIC 值のバラッキを調べたところ, 最高値 と最低值の変動幅が 2 倍の範盲内の正規分布となつた。 したがつて著者らの方法は $2 \sim 3$ 回の実験值の平均值を MIC 值とすることができることを意味する。

著者らの方法の利点は, 平板表面では極度に増殖しに くいL. acidophilus や L. bulgaricus はもとより, 親 株よりは好気化した Bifidobacterium の変異株（乳酸桿 菌よりははるかに高い娧気度を要求する）でさえも充分 に感受性值を測定できることである。実施にさいして留 意すべき点は，（i）供試菌濃度と接種量，（ii）平板の乾 燥度（使用日に調製する），(iii）ディスクを置いたあと の放置時間，（iv）菌接種後すみやかにディスクを置く の 4 点である。供試菌の age は特に検討しなかつたが， 少なくとも PC-G では 16 時間, 24時間培養菌およびこ れらを $4 \mathrm{C}$ に 20 時間保存した菌では差がみられなかつ た。

乳酸桿菌の場合耐性度 (感受性度) 分布を基礎として その耐性を論じた報告はみられない。このような状況下
で乳酸柏菌の耐性を論じても耐性の根拠が不 確 実であ る。著者らは乳酸桿菌の抗生物質感受性分布から耐性值 の下限を推定するとともに実験室で分離した耐性菌と比 較しながら考察した（表 6 )。表中の耐性值の下限は，一 部の例外はあるが一応分布のとぎれる濃度を目安として 定めた。この值を赤浰菌 ${ }^{13)}$, 㨀気性菌 ${ }^{16)}$ ， その他乳酸桿 菌以外の細菌4,7,11) で得られている值と比較すると，乳 酸桿菌の KM, FRM, PRM の耐性值の下限（正確な 值は不明であるが）は，他の細苜の值よりはるかに高い 值を示している。他の抗生剤については，他の細菌群で 得られている值と本質的に変らないので, 乳酸桿菌の抗 生物質感受性の度合は他の細菌群と変らないことを示す と思われる。いずれにしても，供試株数が34株と少ない ので, 今後新鮮分離菌を含む多数の菌株を用いて, さら に感受性分布や耐性值の下限について検討を加えたい。

表 6 の耐性值の下限を参考にして，L. casei YIT0091 およびその耐性菌の感受性值を比較すると， L. casei YIT0091 株の KM, FRM, PRM に対する MIC 值 
Table 6. Thresholds of drug-resistance assessed from distribution of sensitivity values, obtained by modified disc method, among Lactobacillus strains

\begin{tabular}{|c|c|c|c|c|}
\hline & \multirow{2}{*}{$\begin{array}{c}\text { Thresholds } \\
\text { of } \\
\text { resistance }\end{array}$} & \multicolumn{3}{|c|}{ MIC mcg per $\mathrm{m} l$} \\
\hline & & $\begin{array}{l}\text { YIT } \\
0091\end{array}$ & $\begin{array}{l}\text { PSR } \\
3002 \\
\end{array}$ & $\begin{array}{l}\text { PSR } \\
3005 \\
\end{array}$ \\
\hline Erythromycin & $1.6 \mathrm{mcg} / \mathrm{ml}$ & 0.019 & $3200^{a}$ & $3200^{a}$ \\
\hline Oleandomycin & 3.2 & 0.41 & $\gg 6400^{a} \geqslant$ & $\gg 6400^{a}$ \\
\hline Leucomycin & 1.6 & 0.10 & $25^{a}$ & $25^{a}$ \\
\hline Spiramycin & 6.3 & 2.18 & $>47$ & $>47$ \\
\hline Tetracycline & $3.2-6.3$ & 0.22 & $25^{a}$ & $25^{a}$ \\
\hline Streptomycin & 3.2 & 45 & $\gg 10000^{a} \geqslant$ & $\gg 10000^{a}$ \\
\hline Kanamycin & $>84$ & 75 & $100^{a}$ & $100^{a}$ \\
\hline Fradiomycin & $>12.5$ & 11 & 8.3 & 13 \\
\hline Paromomycin $>$ & $>12.5$ & 11.5 & 11.2 & 12 \\
\hline Chloramphenico & ol 6.3 & 3.4 & - & - \\
\hline Mikamycin & 1.6 & 0.38 & - & - \\
\hline Lincomycin & 6.3 & 0.21 & 3.6 & 4.7 \\
\hline Penicillin $\mathrm{G}^{b}$ & 1.6 & 0.49 & - & - \\
\hline Cephaloridine & 12.5 & 3.4 & 8.3 & 8.9 \\
\hline Cephalothin & $12.5-25$ & 17.5 & 8.9 & 15 \\
\hline Noboviocin & 12.5 & 3 & 一 & - \\
\hline $\begin{array}{l}\text { Dehydroxyme- } \\
\text { thylfractoridine }\end{array}$ & $e^{12.5-25}$ & 7.4 & - & - \\
\hline
\end{tabular}

a $\operatorname{MTC}(\mathrm{mcg} / \mathrm{m} l)$ determined by agar dilution method.

b unit $/ \mathrm{m} l$.

PSR 3002 and 3005 are multilple drug resistant mutants derived from $L$. casei YIT 0091.

は, 感受性の病原細菌の MIC 值 ${ }^{4,7,8,12)}$ に比べて高い值 であるが，乳酸桿菌全般からみた場合耐性菌とは判定で きない。同様に耐性菌（PSR3002，3005）の LCM の MIC 值が親株と比較して15２5倍増加しているが，乳 酸桿菌全般からみると耐性菌とは判定しがたい。このよ うに乳酸桿菌の個々の菌株の耐性を扱う場合, 耐性值の 下限を考虑して論ずべきであろう。

感受性分布を調べた段階で，高濃度の自然耐性菌は検 出されなかつた。しかし供試株のうちで L. casei YIT 0091 , L. casei I-136, L. fermenti F-1, L. salivarius S-561, L. plantarum P-16 は, 9〜10 種類の抗生剤に 対して $2 \mu \mathrm{g} / \mathrm{ml}$ 以上の $\mathrm{MIC}$ 值をもつことから比較的 抵抗性の強い株であることが示唆された。また L. casei YIT0091 株は，抗結核風，サルファ風に対しても非常 に強い抵抗性を示した。
腸内細菌に対する抗生剤の影響は, in vivo で $\mathrm{CP}^{14)}$, $\mathrm{LM}, \mathrm{EM}$ および $\mathrm{PC}-\mathrm{V}^{10)}$ について報告されている。こ れらによれば，各抗生凨に対する MIC が1.6〜 $12.5 \mu \mathrm{g}$ または unit $/ \mathrm{ml}$ の腸球囷や大腸菌では，CP $500 \mathrm{mg} /$ 日 で7日間あるいは LM $1 \mathrm{~g} /$ 日で 6 日間投与しても菌数 の減少はなく，また EM $1 \mathrm{~g} /$ 日で 6 日または PC-V 100 万笚位/日 6 日投与してはじめて菌数が 10〜0.001\%に減 少する。したがつて, $2 \mu \mathrm{g} / \mathrm{m} l$ 以上の MIC 值をもつ菌 は, in vivo において抗生夙存在下でもじゅうぶんに抵 抗できることを意味し，少なくとも L. casei YIT0091

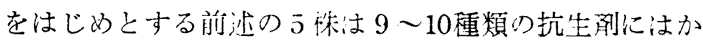
なりの程度まで抵抗し得るこレが示陵される。

\section{文献}

1) Adams, M. H. (1959): Methods of study of bacterial viruses. In Bacteriophages, New York, Interscience Publishers.

2) 安孫子 惇(1971)：消化器病の彭断，80页掞よ び120-122頁, 東京, 南山堂.

3) Branch, A., Starkey, D. H., and Power, E. E. (1965): Diversifications in the tube dilution test for antibiotic susceptibility of microorganisms. Appl. Microbiol., 13, 469472 .

4) Coonrod, J. D., Leadley, P. J., and Eickhoff, T. C. (1971): Antibiotic susceptibility of bacillus species. J. Infect. Dis., 123, 102-105.

5) Efthymiou, C., and Hansen, P. A. (1962): An antigenic analysis of Lactobacillus acidophilus. J. Infect. Dis. 110, 258-267.

6) Garrod, L. P., and Waterworth, P. M. (1971): A study of antibiotic susceptibility testing with proposals for simple uniform methods. J. Clin. Pathol., 24, 779-789.

7) Garrison, D. W., Dehaan, R. M., and Lawson, J. M. (1967): Comparison of in vitro antibacterial activities of 7-chloro-7deoxylincomycin, lincomycin, and erythromycin. Antimicrob. Agents Chemother., 1, 397-400.

8）小酒井 望(1955)：細菌の薬咸耐性, 6-18頁 および141-144頁, 東京, 医学書院.

9）楠井賢造(1972)：スモンの治療指針, 日本医事 新報, No. 2502, 43-47.

10）牧 克己(1958）：抗生物質投与による腸内細菌 鋠の変動についての研究(3) ペニシリン，エリ スロマイシンおよびロイコマイシン経口投与例, 日細菌誌，13，413-418.

11) Matsen, J. M., Koepcke, M. J. H., and Quie, P. G. (1969) : Evaluation of the Bauer-Kirby-Sherris-Turck single-disc diffu- 
sion method of antibiotic susceptibility testing. Antimicrob. Agents Chemother., 1, 445-453.

12) Matsen, J. M., Blazevic, D. J., and Chapran, S.S. (1969): In vitro susceptibility patterns of beta-hemolytic streptococci. Antimicrob. Agents Chemother., 1, 485-488.

13）三橋 進(1970)：薬凨と耐性菌，33～83頁，東 京, 南江堂.

14）篠田増雄 (1961)：抗生物質投与による腸内菌叢 の変動についての研究(4) クロラムフェニコー
ル投与例，日細菌誌，16，128-133.

15) Schoenknecht, F. D. (1973) : The KirbyBauer Technique in clinical medicine and its application to carbenicillin. J. Infect. Dis., 127, S 111-S 115.

16) Wilkins, T. D., Holdeman, L. V., Abramson, L. J., and Moore, W. E. C. (1972): Standardized single disc methods for antibiotic susceptibility testing of anaerobic bacteria. Antimicrob. Agents Chemother., 1, 451459 .

\title{
Studies on Biological Characteristics of Lactobacillus
}

\section{A Modified Method for the Antibiotic Susceptibility Test of Lactobacillus}

\author{
Kiyoshi TOHYAMA and Tsuneo TERASHIMA
}

Yakult Institute for Microbiological Research, Kunitachi, Tokyo 186

A modified single-disc diffusion method was devised for determination of the antibiotic susceptibility of Lactobacillus by using the soft agar overlayer technique, which had been originally designed for phage titration. In this method, all the test strains of Lactobacillus could grow well on soft agar.

The minimum inhibitory concentrations (MIC), as determined by the modified disc method, of six antibiotics (tetracycline, lincomycin, erythromycin, oleandomycin, penicillin G, and chloramphenicol) disagreed with those determined by the agar and tube dilution methods, but were very close to the maximum tolerant concentrations (MTC) for visible growth estimated by the latter methods. Those data were obtained successfully by using constant inocula $(0.1 \mathrm{~m} l)$ of overnight cultures with $130-160$ Klett units.

A total of 34 strains of Lactobacillus were tested for in vitro sensitivity to 17 antibiotics. As a result, the antibiotics of the streptomycin group were inactive against all the test strains, except $L$. acidophilus and L. jugurti. The antibiotics of the macrolide group, mikamycin, penicillin $G$, and tetracycline were the most active against almost all the strains. The sensitivity to cephalothin varied with the species and was low in $L$. casei. The sensitivity of the test strains to 4 antibiotics (cephaloridine, novobiocin, dehydroxymethylfractoridine, and lincomycin) ranged widely from high to relatively low. 